\title{
Very highly prevalent Macracanthorhynchus hirudinaceus infection of wild boar Sus scrofa in Khuzestan province, south-western Iran
}

\author{
G. R. MOWLAVI ${ }^{1}$, J. MASSOUD ${ }^{1}$, I. MOBEDI ${ }^{1}$, S. SOLAYMANI-MOHAMMADI ${ }^{1}$, \\ M. J. GHARAGOZLOU ${ }^{2}$, S. MAS-COMA ${ }^{3}$
}

\begin{abstract}
${ }^{1}$ Department of Medical Parasitology and Mycology, School of Public Health and Institute of Public Health Research, Tehran University of Medical Sciences, P.O. Box 6446, Tehran 14155, Iran, E-mail: molaviva@tums.ac.ir; ${ }^{2}$ Department of Pathology, Faculty of Veterinary Medicine, University of Tehran, P.O. Box 6453, Tehran 14155, Iran; ${ }^{3}$ Departamento de Parasitología, Facultad de Farmacia, Universidad de Valencia, Av. Vicent Andrés Estellés s/n, 46100 Burjassot, Valencia, Spain, E-mail: S.Mas.Coma@uv.es
\end{abstract}

\begin{abstract}
Summary
An epidemiological and pathological study of Macracanthorhynchus hirudinaceus infection in a total of 50 wild boars Sus scrofa attila from cane sugar fields of Iranian Khuzestan was performed. The total prevalence of $64.0 \%$ detected is the highest hitherto known by this acanthocephalan species in wild boars and may reflect a very high contamination of the farm lands studied as the consequence of the crowding of the wild boar population in cane sugar fields. Observations prove that this species is a wild boar gut wall perforating acanthocephalan. High burdens may become so pathogenic for the host individual as to be responsible for its elimination from the population. Thus, this acanthocephalan may play a role in the control of the $S$. scrofa population inhabiting cane sugar fields, only lowly infected boars being able to survive. In this way, $M$. hirudinaceus may be useful, as the wild boar is a serious pest of field corps and, moreover, causes a variety of damage to cane sugar fields because of using them for shelter and nesting areas. Such high prevalence in wild boars and presumably high contamination of cane sugar fields represent a human infection risk for farmers, as well as for concrete ethnic group minorities in Iran. The numerous M. hirudinaceus human infection cases reported so far, mainly in Asian countries, support such a risk situation.
\end{abstract}

Key words: Macracanthorhynchus hirudinaceus; epidemiology; pathology; wild boar; Khuzestan province; Iran

\section{Introduction}

The wild boar, Sus scrofa Linnaeus, 1758 (Mammalia: Suiae) is distributed throughout Eurasia. Among its several subspecies, S. s. attila Thomas, 1912 is the one that occurs in Iran (Ellerman \& Morrison-Scott, 1966; Herre, 1986).
Although no accurate estimate of the Iranian wild boar population is available at present, it is evident that this animal is a frequent inhabitant of regions of dense forests in the north, north-west, west and south-west of this country owing to the abundance of diet. Of omnivorous characteristics and high adaptation capacity, this animal includes seeds, fruits, mushrooms, reptiles, amphibians, insect larvae, birds and their eggs, small rodents and even carrion in its diet (Etemad, 1985). This may explain the diversity of helminths having been detected in wild boars in Iran (Eslami \& Farsad-Hamdi, 1992; Solaymani-Mohammadi et al., 2003).

Among the helminths of wild boars in Iran, the giant thorny-headed worm Macracanthorhynchus hirudinaceus (Pallas, 1781) Travassos, 1917 [= Echinorhynchus gigas (Goeze) Bloch, 1782 - see Golvan, 1994] (Acanthocephala: Class Archiacanthocephala, Fam. Oligacanthoryhnchidae) is worth noting because of the prevalences detected, i.e. a $41.6 \%$ in Luristan province (Solaymani-Mohammadi et al., 2003). Such a prevalence is markedly high, taking into ac-count that thorny-headed worms are fairly rare when com-pared with parasitic platyhelminths or nematodes. This acanthocephalan follows a two-host life cycle using grubs and adult insects (mainly beetles of the family Scarabaeidae) as intermediate host and predaceous birds and mammals as definitive hosts (Kates, 1943). So, this species may be found in a broad spectrum of hosts. In Iran, this species has even been found in canids (Arbabi et al., 2001).

Specialists do accept $M$. hirudinaceus to be a cosmopolitan species (Golvan, 1994). It is widespread in the world, with swine, wild boars and peccaries serving as final hosts. A history of either accidental or intentional ingestion of arthropods, usually beetles, is related to human infection. 
Macracanthorhynchus hirudinaceus is the most frequent agent of acanthocephaliasis. Most of the several hundred infections documented in humans are from Asia (Neafie \& Marty, 2000).

In Iran, the wild boar has been approaching human settlements in rural areas of the Khuzestan province, probably due to the extended dryness suffered in many Iranian regions in the last five years. Such close proximity may accelerate the direct contact of boars with farm lands resulting in their contamination by the parasites of the wild boar. This may increase the chance of transmission of the parasite to human communities.

As no parasitological data on wild boar in Khuzestan province are available, despite the large population of this animal, a survey to ascertain the epidemiological characteristics of $M$. hirudinaceus was undertaken. Owing to the unexpectedly very high prevalence detected, a pathological study was additionally performed. Pathogenesis caused by acanthocephalans can be severe, but little consideration has been given to the effects of this group of parasites as a controlling factor of wildlife populations.

\section{Material and Methods}

Study area

Surveys were carried out in cane sugar fields of the Karoon Cane Sugar Agro-Industrial Company. The vast farms under cane sugar cultivation of this company are part of Khuzestan province, located near the Karoon River, about 20 $\mathrm{km}$ far away from Shooshtar, in the south-western part of Iran. For decades, this mechanised farming company with its several factories using cane sugar as crude materials in their production steps, has become one of the most successful economic centres in the country, and is at present analysing the possibility to expand. Many hectares land are under mechanised cane sugar cultivation and this vast and protected area has provided a suitable shelter and nesting area for wild boars because of its faunal diversity and water resources. Despite the high density of the wild boar population in the cane sugar fields ( $>50000$ hectares) and the lack of major geographical barriers, this suid has not shown a trend to spread outside the Karoon Agro-Industrial lands. Nowadays, in the absence of natural enemies and illegal hunters, $S$. scrofa is considered to be the most important vertebrate pest, causing wide damage to the cultivated farms.

\section{Parasite collection}

A total of 50 wild boars (42 females and 8 males; 33 young and 17 adult specimens) was collected thanks to an authorised hunting programme from September 2002 to July 2003. This activity was part of a schedule designed for vertebrate pest control in the Karoon Agro-Industrial Company. Records were kept of age (young or adult, according to physical appearance) and gender. After applying the formol-ether concentration technique (Knight et al., 1976), careful examination of stools under a microscope was carried out for a first determination of parasitosis. At necropsy, the entire intestinal tract was removed, divided into anatomical parts, opened longitudinally and walls were examined for the worms and any pathogenic lesions. All acanthocephalans were recovered and placed in containers with normal saline solution for worm relaxing. Worms were afterwards transferred to another container for fixation with buffered $10 \%$ formalin. Worm size and characteristic measures together with the number and arrangement of the hooks on the proboscis were analysed to confirm the identification as M. hirudinaceus.

\section{Tissue sample collection}

Additionally, tissue samples from the affected intestinal sites and worm proboscides embedded in the intestinal walls were cut and preserved in the same fixative solution. Any other macroscopic injuries were also included, labelled and transported to the laboratory of the Ahvaz Educational and Health Research Centre for further investigations. Intestinal tissues in which the proboscis was deeply embedded and other similar lesions were selected for histopathological examinations. After dehydration and cleaning in xylol, the samples were embedded in paraffin. A total of ten 5 - $\mu \mathrm{m}$ histological slides of each sample was stained with Harris hematoxylin-eosin (HE). Each slide was studied thoroughly under a light microscope and analysed and photographed by means of a computer image analysis system (CIAS) including a computer connected to a 3CCD color video camera (Sony DXC-930P) applied to a microscope, using image analysis software (Optimas 5, Optimas Corporation, Seattle, USA).

Table 1. Extreme values and mean measures of distintive features (in mm) of 19 females and 6 males of Macracanthorhynchus hirudinaceus found in wild boars

\begin{tabular}{|c|c|c|c|c|}
\hline \multirow[t]{2}{*}{ Measurements } & \multicolumn{2}{|c|}{ Females } & \multicolumn{2}{|c|}{ Males } \\
\hline & $\min -\max$ & mean & $\min -\max$ & mean \\
\hline Total body length & $110-400$ & 256.8 & $70-140$ & 99.4 \\
\hline Width at mid-body & $3.00-5.00$ & 4.36 & $3.00-3.70$ & 3.30 \\
\hline Praesome length & $1.28-1.45$ & 1.35 & $1.25-1.28$ & 1.26 \\
\hline Proboscis length & $0.78-0.83$ & 0.80 & $0.71-0.79$ & 0.78 \\
\hline Proboscis row No. & $5-6$ & 5.2 & $5-6$ & 5.2 \\
\hline Hook No. per row & $6-9$ & 6.9 & $6-8$ & 6.8 \\
\hline Hook length & $0.162-0.193$ & 0.184 & $0.140-0.161$ & 0.155 \\
\hline
\end{tabular}




\section{Results}

A total of 153 worms (111 females and 42 males) was recovered. Results of measurements made on adult worms are noted on Table 1 . Symmetrically ovoid eggs, including a fully developed acanthor, were 68.9 - $92.9 \mu \mathrm{m}$ (mean $83.6 \mu \mathrm{m}$ ) long and $45.9-57.4 \mu \mathrm{m}$ (mean $52.3 \mu \mathrm{m}$ ) wide.

Among the 50 wild boars examined, the total prevalence was $64.0 \%$. The distribution of $M$. hirudinaceus infection according to host gender and age is shown in Table 2. No significant results can be obtained in the comparison between female and male hosts, because the number of males examined was too low. Wild boar adults were more infected than young host specimens.

The number of adult worms recovered per wild boar varied from 1 to 12 (mean 3.06). The distribution of the different infection intensities (number of adult worms found in the intestine) in the host population is shown in Fig. 1. The mean sex ratio of the worms was $0.3 / 1.0$ males/females.

In all infected boars, the presence of worms was well evident, either by their apparent movement inside the intestinal lumen or through the white-reddish nodules which were observed on the outer surface of the small intestine wall, and which were indicating the invaded site of the intestinal wall by the worm proboscis (Fig. 2 A-C). Calcificationss were seen in a number of affected serosal surfaces of the small intestine. In most cases, the infected animals were suffering from local trauma and frequently the intestinal wall was not completely perforated. In one case, a M. hirudinaceus female had passed through the intestinal wall and was found alive in the peritoneal cavity.

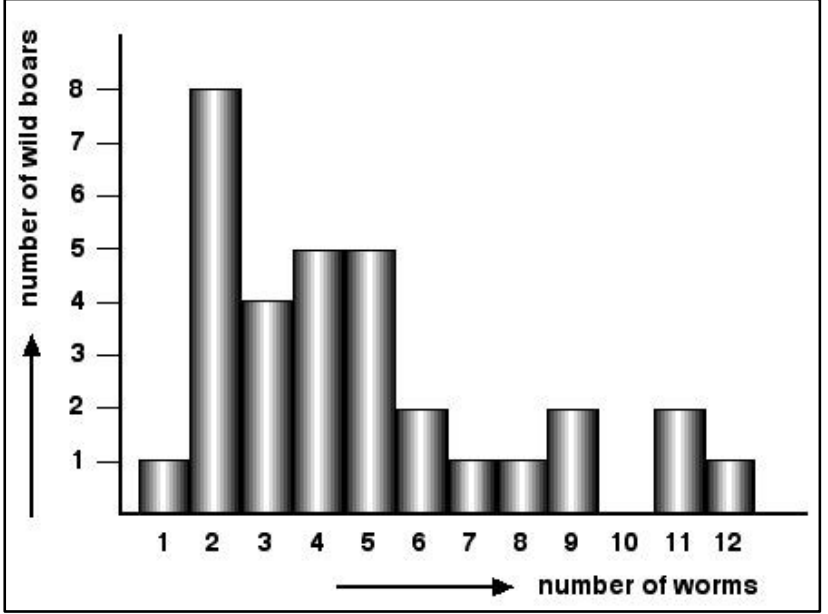

Fig. 1. Distribution of different Macracanthorhynchus hirudinaceus intensities in the wild boar population studied

chronic inflammatory reactions characterised by the presence of eosinophils were seen (Fig. 2 D-I).

\section{Discussion}

Size and measures of $M$. hirudinaceus worms found, as well as length and width of eggs detected in stools, agree with the general description of this acanthocephalan speies (Petrochenko, 1956 - 1958). The age analysis furnished

Table 2. Results obtained in 50 wild boar examination for the detection of Macracanthorhynchus hirudinaceus infection, according to host gender and age

\begin{tabular}{|c|c|c|c|c|c|c|c|c|c|c|}
\hline \multirow{3}{*}{ Type of Sample } & \multicolumn{10}{|c|}{ Sus scrofa attila } \\
\hline & \multicolumn{2}{|c|}{ Females } & \multicolumn{2}{|c|}{ Males } & \multicolumn{2}{|c|}{ Young } & \multicolumn{2}{|c|}{ Adult } & \multicolumn{2}{|c|}{ Total } \\
\hline & No. & $\%$ & No. & $\%$ & No. & $\%$ & No. & $\%$ & No. & $\%$ \\
\hline Eggs in stools & 8 & 19.0 & 1 & 12.5 & 4 & 12.1 & 5 & 29.4 & 9 & 18.0 \\
\hline Worms in intestine & 29 & 69.0 & 3 & 37.5 & 19 & 57.6 & 13 & 76.4 & 32 & 64.0 \\
\hline
\end{tabular}

At the site of attachment of the worm proboscis to the intestinal wall, the lamina propria showed hyperaemic and oedematous changes. Parasite penetration was not limited to the submucosa and outer serosal surface of the intestine, but reaches deeply into the tunica muscularis. Worms were causing destruction of villi and erosion of the epithelium. Severe infiltration of lymphocytes, eosinophils and, with a lower degree, macrophages could be observed at the site of proboscis attachment to the intestinal villius. Deposition of fibrinous exudate was also prominent in many cases. The glandular structures of the small intestine were, in most cases, distended and filled with mucous materials. Additionally, the intestinal area near the site of worm attachment appeared necrotic, degenerated and partially infiltrated by inflammatory cells. In older sites of worm penetration, results which show an increase of the number of worms during wild boar life.

The total prevalence of $64.0 \%$ detected is the highest hitherto known by $M$. hirudinaceus in wild boars. Although prevalences in wild boar in Europe appear to be lower (21 \%) (De-La-Muela et al., 2001), somewhat higher prevalences $(41.6 \%)$ were already found in Iran (SolaymaniMohammadi et al., 2003). The very high prevalence in Khuzestan may reflect a very high contamination of the farm lands studied as the consequence of the crowding of the wild boar population in cane sugar fields.

Moreover, it has to be taken into account that $M$. hirudinaceus eggs are very resistant, remaining infective in soil for up to $1.2-3$ years and tolerating both desiccation and very cold temperatures below $0^{\circ} \mathrm{C}$ (Marquardt et al., 2000). 


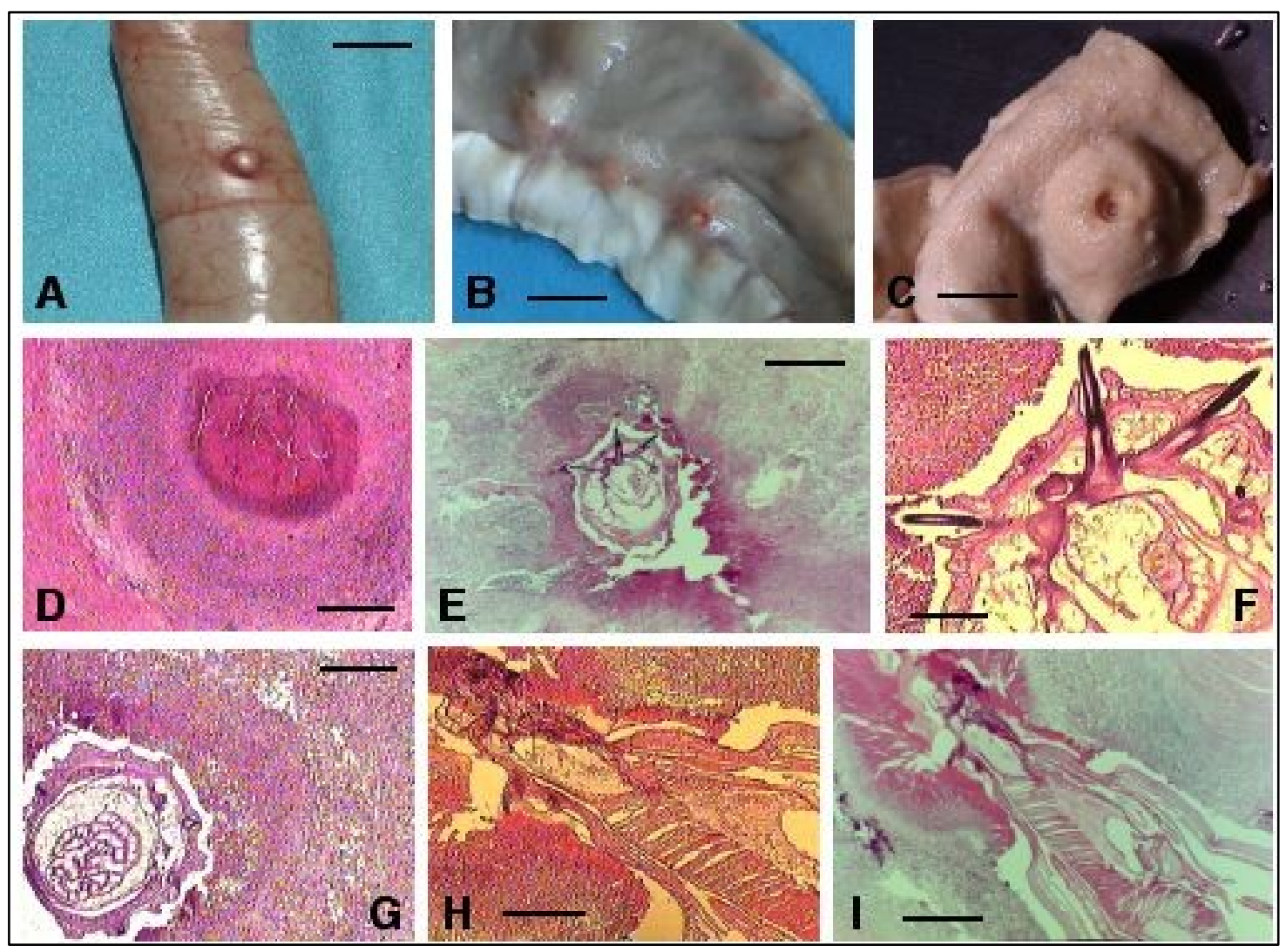

Fig. 2. Pathology induced by Macracanthorhynchus hirudinaceus in wild boar: A) a fibrotic nodule caused by the attachment of worm proboscis to the intestinal wall, visible from serosal surface; B) local trauma and haemorrhages around the site of the worm heads invading the intestinal tissue in the early stages; C) in old lessions, the worms might give up the anchored places of the intestinal wall; this empty hole shows a chronic formation of fibrotic tissues; both acute and chronic reactions can be seen in the same host individual; D) newly invaded site of the intestine typically demonstrating the haemorrhage and inflammation causing severe injury to the tissue; E, G) cross sections at the level of praesome of acanthocephalan armed head causing severe infiltration of mononuclear and polynuclear cells, with a lower number of macrophages; F) the powerful and invasive hooks of the armed worm proboscis can produce tissue damage causing destruction of villi and erosion of epithelium; H, I) penetration tend to be continuous into the deeper layers of intestine near to the serosal surface; lamina propria around the proboscis has intense infiltration by neutrophils, eosinophils and plasma cells; this area shows hyperaemic and oedematous changing. $\mathrm{Scale}$ bars: $\mathrm{A}=10.5 \mathrm{~mm} ; \mathrm{B}=7.5 \mathrm{~mm} ; \mathrm{C}=4.5$ $\mathrm{mm} ; \mathrm{D}, \mathrm{E}=500 \mu \mathrm{m} ; \mathrm{F}=100 \mu \mathrm{m} ; \mathrm{G}, \mathrm{H}=300 \mu \mathrm{m} ; \mathrm{I}=450 \mu \mathrm{m}$

Additionally, dung beetles are abundant in the rural areas of Iran, especially in the warm months of late spring and summer (Mobedi et al., 1971). Throughout the cultivated areas in which this study took place, the presence and activities of the scarabeid populations were well visible because of their high densities, mainly in the warmer days and around sunset time. The newly hatched larvae of this group of beetles feed on the fine feeder roots of grasses. As soil temperatures cool in late fall, grabs migrate down into the soil and hibernate for the winter.

Interestingly, in spite of the very high prevalence, the infection intensity detected does not appear to be high. The recognised high pathogenicity of $M$. hirudinaceus may be related to this fact. This acanthocephalan causes serious damage to the intestinal mucosa, primarily traumatic and accompanied by great pain, by penetration of the proboscis, and is compounded by the tendency of the worm to release its hold occasionally and reattach at another place. Complete perforation of the gut sometimes occurs, and this may be rapidly fatal for the host. Moreover, those effects are usually increased by secondary bacterial infection responsible for localised and generalised peritonitis, haemorrhage and other complications as pericarditis, myocarditis, arthritis, and cholangiolitis (Nelson \& Nickol, 1986; Zhao et al., 1990; Neafie \& Marty, 2000). Observations made in wild boars of the Khuzestan province fully agree with this and prove that this species is a wild boar gut wall perforating acanthocephalan, as already observed in humans (Radomyos et al., 1989) and contrarily to what was seen in domestic pig (Zhao et al., 1990). In swine infections by a Nearctic, non-perforating, close species of the same genus, Macracanthorhynchus ingens (von Linstow, 1879) Meyer, 1932, also recorded in humans (Dingley \& Beaver, 1985), penetration is limited to the submucosa, and the effects are not as severe as those occurring in the presence of $M$. hirudinaceus, which enters deeply into the tunica muscularis (Nelson \& Nickol, 1986).

This high pathogenicity may explain the relatively low infection intensities detected in a highly prevalent wild boar population crowded in the Karoon Agro-Industrial lands, a result which do not agree with the general observations made in helminth faunas of mammals inhabiting isolated 
ecosystems, where prevalences higher than in open mainlands are also accompanied by higher intensities (Mas-Coma, 1979; Mas-Coma \& Feliu, 1984; Mas-Coma \& Esteban, 1988). Similarly, the relatively little inflammatory responses detected in many boars of the present study may also suggest relatively recent infections, as deep proboscis penetration and more extensive encapsulating reactions with necrotic/inflammatory tissue in its inner part and filamentous connective tissue in its outer part, appear after almost 3 month infections (Zhao et al., 1990). Additionally, the higher number of wild boars harbouring a lower number of adult worms (Fig. 1) despite results indicating an increase of the number of acanthocephalans in the intestine with age, could also be suggestive of high burdens becoming so pathogenic for the host individual as to be responsible for its elimination from the population.

Thus, $M$. hirudinaceus may play a role in the control of the S. scrofa population inhabiting the Karoon Agro-Industrial lands. Such a host population regulation capacity by helminths has already been suggested to take place in isolated ecosystems (Mas-Coma et al., 1987).

In this way, $M$. hirudinaceus may be useful, as $S$. scrofa is a serious pest of field corps and, moreover, causes a variety of damage to cane sugar fields because of using them for shelter and nesting areas. The most common complaint is rooting (sometimes called grubbing), resulting in the destruction of the newly cultivated plots. They dig up cattails and reeds for roots and tubers, just turning the soil over and then moving on and picking another place. At present, to prevent cane sugar fields from the serious damages caused by the non-stop increasing wild boar populations, the only control method used in the field is killing wild boars by shooting them with guns.

In Iran, despite breeding and consumption of pork being prohibited in accordance with Islamic instructions and public culture, and although no human infections have been reported, it is evident that such high prevalence in wild boars and presumably high contamination of cane sugar fields represent a human infection risk for farmers by accidental ingestion of cystacanth-infected intermediate hosts. Similarly, they can be dangerous for ethnic group minorities as Christian Armenians and gypsy tribes who gain still considerable access to wild boar areas for illegal hunting. The numerous $M$. hirudinaceus human infection cases reported so far, mainly in Asian countries such as China (Leng et al., 1983; Zhong et al., 1983) and Thailand (Pradatsundarasar \& Pechranond, 1965; Chaiyaporn, 1967; Kliks et al., 1974; Tesana et al., 1982; Hemsrichart et al., 1983; Radomyos et al., 1989), and also Russia (Schmidt, 1971), support such a risk situation. In China, in more than 200 patients operated it was found that intestinal perforation was caused by this worm. Additionally, 115 patients infected by this acanthocephalan were found among those complaining of acute abdominal pain (Leng et al., 1983).

\section{Acknowledgements}

The authors are grateful to the School of Public Health and
Institute of Public Health Research, Tehran, for providing financial support. Thanks are due to the Karoon Agro-Industrial Company and the Khuzestan Environment Protection Organisation for work facilitation. We are also indebted to the personnel of the Ahvaz Educational and Health Research Centre linked to the Tehran University of Medical Sciences. The collaboration of Dr. M.A. Valero (Valencia, Spain) in the use of the computer image analysis system (CIAS), and of Dr. B.S. Dezfuli (Ferrara, Italy) in taxonomical aspects is greatly appreciated.

\section{References}

Arbabi, M., Doroodgar, A., Hooshyar, H., Asadi, M. A., MoBEDI, I. (2001): Macracanthorhynchus hirudinaceus in carnivores of Kashan region, Iran. In: Third National Congress of Medical Parasitology, Sari, Iran

CHAIYAPORN, V. (1967): Discovering of two kinds of parasites in Thailand. J. Med. Ass. Thailand, 50: $834-838$

De-La-Muela, N., Hernandez-De-Lujan, S., Ferre, I. (2001): Helminths of wild boar in Spain. J. Wildl. Dis., 37: $840-843$

DINGLEY, D., BEAVER, P. C. (1985): Macracanthorhynchus ingens from a child in Texas. Am. J. Trop. Med. Hyg., 34: $918-920$

Ellerman, J. R., Morrison-ScotT, T. C. S. (1966): Checklist of Palaearctic and Indian Mammals 1758 to 1946. Trustees of the British Museum (Natural History), London

Eslami, A., FARSAD-HAMdi, S. (1992): Helminth parasites of wild boar, Sus scrofa, in Iran. J. Wildl. Dis., 28: $316-$ 318

ETEMAD, E. (1985): The mammals of Iran, Vol. 2. Iranian Environmental Protection Organization (IEPO) Press, Tehran (in Persian)

Golvan, Y. J. (1994): Nomenclature of the Acanthocephala. Res. Rev. Parasitol., 54: 135 - 205

Hemsrichart, V., Pichyangkura, C., Chitchang, S., VutichAMNONG, U. (1983): Eosinophilic enteritis due to Macracanthorhynchus hirudinaceus infection: report of 3 cases. J. Med. Ass. Thailand, 66: $303-310$

HERRE, W. (1986): Sus scrofa Linnaeus, 1758 - Wildschwein. In NiETHAMMER, J. and KRAPP, F. (Eds): Handbuch der Säugetiere Europas. Paarhufer. AULA-Verlag GmbH, Wiesbaden, Band 2/II: $36-66$

KATES, K. C. (1943): Development of the swine thornheaded worm, Macracanthorhynchus hirudinaceus, in its intermediate host. Am. J. Vet. Res., 4: $173-181$

Kliks, M., Tantachamrun, T., Chaiyaporn, V. (1974): Human infection by an acanthocephalan Macracanthorhynchus hirudinaceus in Thailand: new light on a previous case. Southeast As. J. Trop. Med. Publ. Health, 5: $303-309$

Knight, W. B., Hiatt, R. A., Cline, B. L., Ritchie, L. S. (1976): A modification of the formol-ether concentration technique for increased sensitivity in detecting Schistosoma mansoni. Am. J. Trop. Med. Hyg., 55: 818 - 823

LENG, Y. J., HuANG, W. D., LiANG, P. N. (1983): Human 
infection with Macracanthorhynchus hirudinaceus Travassos, 1916 in Guangdong Province, with notes on its prevalence in China. Ann. Trop. Med. Parasitol., 77: 107 109

Marquardt, W. C., Demaree, R. S., Grieve, R. B. (2000): Parasitology and Vector Biology, $2^{\text {nd }}$ Edition. Academic Press, London

MAS-COMA, S. (1979): Parasitofauna insular. La problemática de los parásitos en ecosistemas insulares. Rev. Real Acad. Farm. Barcelona, 21: 3 - 28

MAs-Coma, S., EstebAn, J. G. (1988): La evolución de una fauna parasitaria en islas "continentales": el caso de los helmintos de micromamíferos en las Baleares y Pitiusas. Bull. Ecol. Paris, 19: $211-218$

MAS-COMA, S., FELIU, C. (1984): Helminthfauna from small mammals (insectivores and rodents) on the Pityusic Islands. In KuhBIER, H., Alcover, J. A. and Guerau D'AREllano TUR, C. (Eds): Biogeography and Ecology of the Pityusic Islands. Monographiae Biologicae 52, Dr. W. Junk Publishers, The Hague: 469 - 525

Mas-Coma, S., Galan-Puchades, M. T., Fuentes, M. V., VAlero, M. M., JimeneZ, A. M. (1987): Sobre la composición cuantitativa de las parasitofaunas insulares: posible efecto regulador de las especies parásitas sobre las poblaciones de sus hospedadores. In SANS-COMA, V., MASComa, S. and Gosalbez, J. (Eds): Mamíferos y Helmintos. Volumen Homenaje al Prof. Dr. Herman Kahmann en su 81 Aniversario. Ketres Editora, S.A., Barcelona: 217 - 251 MoBedi, I., ARFAA, F., VEDADI, I. (1971): The possible role of dung-pusher beetles in the epidemiology of intestinal helminths. Bull. Soc. Pathol. Exot., 64: $924-925$

Neafie, R. C., Marty, A. M. (2000): Acanthocephaliasis. In Meyers, W. M., Neafie, R. C., Marty, A. M. and WEAR, D. J. (Eds): Pathology of Infectious Diseases, Vol. 1 Helminthiases. Armed Forces Institute of Pathology and American Registry of Pathology, Washington D.C.: $519-$ 529

RECEIVED JANUARY 28, 2004
Nelson, M. J., Nickol, B. B. (1986): Survival of Macracanthorhynchus ingens in swine and histopathology of infection in swine and raccoons. J. Parasitol., 72: 306 - 314 Petrochenko, V. I. (1956 - 1958): Acanthocephala of Domestic and Wild Animals. Vol. I and II, SKRJABIN, K.I. (Ed), Izdatel'stvo Akademii Nauk SSR, Moskva, 465 478

Pradatsundarasar, A., Pechranond, K. (1965): Human infection with the acanthocephalan Macracanthorhynchus hirudinaceus in Bangkok: report of a case. Am. J. Trop. Med. Hyg., 14: $774-776$

RAdOMYos, P., CHOBCHUANCHOM, A., TungtRongChITR, A. (1989): Intestinal perforation due to Macracanthorhynchus hirudinaceus infection in Thailand. Trop. Med. Parasitol., 40: 476-477

SCHMIDT, G. D. (1971): Acanthocephalan infections of man, with two new records. J. Parasitol., 57: 582 - 584

Solaymani-Mohammadi, S., Modedi, I., ReZaian, M., Massoud, J., Mohebali, M., Hooshyar, H., Ashrafi, K., ROKNI, M. B. (2003): Helminth parasites of the wild boar, Sus scrofa, in Luristan province, western Iran and their public health significance. J. Helminthol., 77: 263-267

Tesana, S., Mitrchai, J., Chunsuttwat, S. (1982): Acute abdominal pain due to Macracanthorhynchus hirudinaceus infection: a case report. Southeast As. J. Trop. Med. Publ. Health, 13: 262-264

ZhaO, B., TARASChEWSKI, B., MeHLHORN, H. (1990): [Light and electron microscopic studies of the histopathogenicity of Macracanthorhynchus hirudinaceus (Archiacanthocephala) in experimentally infected domestic swine]. Parasitol. Res., 76: 355 - 359 (in German)

ZHONG, H. L., FenG, L. B., WANG, C. X. (1983): Human infection with Macracanthorhynchus hirudinaceus causing serious complications in China. Chin. Med. J., 96: $661-$ 668

ACCEPTED MAY 19, 2006 